\title{
Social Entrepreneurship in Hospitality Industry. The Case of Operators at the Coastal Tourism Circuit in Kenya
}

\author{
Ikwaye Sam \\ KAHC \\ eo-coast@kahc.co.ke \\ Ogembo O. John \\ Kenyatta University \\ jogemboh@yahoo.com \\ Kiarie Bernadett \\ Kenyatta University \\ bernakiarie2004@yahoo.co.uk
}

\begin{abstract}
The study was necessitated by paucity in empirical data on extent of adoption of social entrepreneurial practices by players in the hospitality industry particularly in developing countries such as Kenya. It aimed at ascertaining the players' social enterprise strategies, the influence of factors on their strategies, the outcomes of the practices and attendant challenges. A total 80 out of 120 hospitality operators within Mombasa, Kwale, Kilifi and Taita Taveta counties within the coastal tourist circuit, Kenya who are registered members of Kenya Association of Hotelkeepers and Caterers (KAHC) completed a questionnaire constructed by the researchers. Results showed that $56.3 \%$ of the respondents had a documented social enterprise strategy which highlighted their entrepreneurial function and social mission. The regression model used showed that background factors accounted for $24.3 \%$ of the total variance in adoption of social enterprise strategy $F(4,80)=6.00, p<.001$; type of management, business location and length of operation being significant predictors with the influence of type of management being positive. Findings on outcomes showed greater involvement of the local community in provision of supplies and services to the hospitality facilities, employment of local community residents and eradication of child sex tourism. Additionally, members reported improved manpower development and observation of statutory requirements as regards payments and compensations for labour, supplies and other services. However, market volatility, restraints due to legal and logistical issues and limited capacity of the local communities to cooperate in provision of some required essential supplies and services among others were indicated to be limiting enhanced adoption of social entrepreneurial practices. The study not only forms a foundation for future studies in social entrepreneurship in hospitality industry in other regions within the country but also other developing ones as well.
\end{abstract}

Keyword: Social entrepreneurship

\section{INTRODUCTION}

The coastal tourist resort towns and generally the Kenyan coastline are dotted by internationally renowned hospitality investments (World Bank, 2010) attributed mainly to its popularity as a holiday destination for both local and foreign tourists (Omondi, 2003). The arrival and presence of these holiday merry makers presents the coastal towns with immense business opportunities as the towns and its environs attempt to accommodate and entertain the revelers (Irandu, 2004; World Bank, 2010).Arguably, while the main aim of these investments is to earn profit for the investors as a return on their investments, it has also been suggested that they should as a matter of principle serve to improve the livelihoods and wellbeing of those living around them. In doing so, they would be seen to serve not only the traditional entrepreneurial functions for the investors but also a social function to the local communities thus turning themselves into social entrepreneurs with an intertwined complex duo function.

Social entrepreneurship which is an emerging discipline within many business schools is defined as an innovative, social value creating activity that can occur within or across the nonprofit, business, and public sectors (Austin, Stevenson \& Wei-Skillern, 2006 as cited in Dzisi\&Otsyina, 2014).A relatively new concept easily confused with corporate social responsibility (CSR) by many, it is the conscious integration of social, cultural, environmental programs into the entrepreneurial programs rather than a once in a while public relation exercise as practiced in CSR. According to Moufakkir and Burns (2012), social entrepreneurship is an agent of change, a global phenomenon which plays a 
significant role in the socio-cultural evolution. It is a dynamic process undertaken by individuals who are proactive, risk-taking, and mission-oriented entrepreneur who decide to replicate a socially-driven venture to a new location in order to catalyze societal and policy reform, through entrepreneurial methodologies that are anchored in innovation and an adaptive spirit (Munoz, 2009).

The evolution according to some researchers is prompted to by the need to implement business models that make profitability and social responsiveness converge particularly important in conflict ridden business environments. Munoz (2009) for instance conceives social entrepreneurs as persons with the ability to make a favorable impact within the business and socioeconomic environment. Again, it has been observed that while the inherent benefit provided by socially-directed activities has not changed over the years, the modalities of implementation have evolved. Davis (2002) observed the emergence of venture philanthropy where wealthy entrepreneurs have implemented venture capitalism approaches to spur and support social change. Previously, Paquet (1997) had cited the growing experimentation of new systems, processes, structures, and organizational alignments, the changing methodologies calling for adoption of social entrepreneurial practices with organizational responses to the evolving nature of the internationalizing contemporary business landscape. Additionally, there is a need to anchor entrepreneurial thinking and venture sustainability in socioeconomic activities. Thompson et al (2000) identified the relevance of vision formulation, leadership ability, and consideration of the long-termimpact of the venture. Mort et al (2003) pointed out the need for value creation alongside efficiencies in management and decision-making, while Over holt et al (2004) alludedto the integration of entrepreneurial thinking and action, concretization of goals and aspirations, and venture continuity.

Evidence show attempts by researchers globally to document social entrepreneurial practices and their attendant benefits by various players in various sectors of the economy. For instance Munoz (2009) enumerates trends and strategic implications of social entrepreneurship in China, Rametse \& Shah (2013) reports on the outcomes of Gram Vikas' mission as achieved through the program called Movement and Action Network for the Transformation of Rural Areas (MANTRA) in which the entrepreneur set out to promote processes which are sustainable, socially inclusive and gender equitable, to enable critical masses of poor and marginalized rural people or communities to achieve a dignified quality of life in Orissa, Eastern India. Similarly, Black and O'Brien (2004) as well as Ewart (2005) discussed the CARE Kenya Rural Entrepreneurship and Agribusiness Promotion (REAP) project whose predominant objective was to increase income of smallholders through commercial horticultural production and marketing opportunities on a sustainable basis. The overall outcome of each of the cases point to the immense benefit that accrue from a sustainable socioeconomic interaction between entrepreneurs and the local community. However, although there are a few studies on social entrepreneurship in the hospitality and tourism sector, most of the studies are focused on the hospitality industry in developed country contexts (Austin et al, 2006; Desa, 2007; Bohdanowicz and Zientra, 2008; Ergul and Johnson, 2011). Very little is known about the hospitality industry in the less developed countries, specifically Kenya. This calls for more empirical research in developing country contexts to further our understanding of social entrepreneurship and what the hospitality entities are doing in pursuance of social entrepreneurship. This is expected to provide empirical basis for the development of social entrepreneurship and to contribute to the theoretical debate in the social entrepreneurship literature, particularly the developing country context. It is on this basis that this study set out to assess social entrepreneurship in the hospitality industry in Kenya with a specific focus on the contributions of operators within the coastal tourist circuit in Kenya.

\section{ObJECTIVES OF THE STUdY}

The overall objective of this study was to determine the extent to which operators in the hospitality industry within the coastal tourism circuit of Mombasa, Kwale, Kilifi and Taita Taveta have embraced social entrepreneurial practices. Specifically, it aimed at answering the following questions:

1. Do the hospitality industry operators have a social enterprise strategy?

2. Do the hospitality industry operators' background factors influence their adoption of social entrepreneurship?

3. What are the outcomes of entrepreneurial strategy adopted by hospitality industry operators?

4. What are the challenges encountered in embracing social entrepreneurship by hospitality industry operators? 


\section{RESEARCH METHODOLOGY}

\section{a. Participants and Procedure}

Participants were 80out of 120 hospitality operators within Mombasa, Kwale, Kilifi and Taita Taveta counties within the coastal tourist circuit, Kenya who are registered members of Kenya association of Hotelkeepers and Caterers (KAHC). Respondents were told that the study aimed at assessing extent to which they had embraced social entrepreneurial practices in their day to day business operations. They completed a questionnaire constructed by the researchers. The use of only members of KAHC was informed by the fact that since issues required for the study bordered on confidential matters, only members of the association could easily give out information particularly to their secretariat.

\section{b. Measures}

Background Variables. Five background factors were considered for the study. These included type of establishment, type of management, type of operation, location of establishment and respondents designation.

Social Enterprise Strategy. Two statements were used to assess the extent to which operators had embraced aspects of social enterprise strategy; all ratings were made on a 5 -point scale $(1=$ Least extent, $5=$ Very great extent). A mean score of each item was computed.

Outcomes. Three statements were used to assess the outcomes of implementation of social enterprise strategy by the operators; all ratings for quantitative statements were made on a 5-point scale $(1=$ strongly disagree, $5=$ strongly agree). A mean score of each item was computed.

Challenges. Two statements were used to determine the challenges encountered in the process of attempting to implement social enterprise strategy.

\section{RESUlts AND DisCuSSION}

\subsection{Descriptives}

Mean, standard deviations, and inter correlations for scores on each of the variables are presented in Table 1 for the total sample.

Table1. Means, standard deviations, and correlations between the variables of the study $(N=80)$

\begin{tabular}{|lllllllllllc|}
\hline \multicolumn{1}{|c}{ Variables } & Mean & SD & 1 & 2 & 3 & 4 & 5 & 6 & 7 & 8 & 9 \\
\hline 1. Establishment type & 1.10 & .439 & - & -.059 & $-.239^{*}$ & $.387^{* *}$ & .199 & .190 & .018 & .022 & -.202 \\
2. Management type & 1.06 & .244 & - & .305 & -.095 & $\mathrm{c}$ & -.015 & .029 & $\mathrm{c}$ & $.293^{* *}$ \\
3. Operation length & 1.94 & .905 & & - & $-.312^{* *}$ & .075 & $-.383^{* *}$ & -.021 & $-.350^{* *}-.079$ \\
4. Business location & 2.19 & 1.08 & & & - & $.267^{*}$ & .066 & -.207 & .176 & $-.271^{*}$ \\
5. Social Strategy1 & 15.25 & 4.40 & & & & - & $.786^{* *}$ & .199 & $-.332^{* *}-.210$ \\
6. Social Strategy2 & 7.13 & 2.35 & & & & & - & $.247^{*}$ & .219 & -.222 \\
7. Outcome 1 & 44.31 & 15.30 & & & & & & - & $.270^{*}$ & .156 \\
8. Outcome 2 & 18.07 & 4.74 & & & & & & & - & -.214 \\
\hline
\end{tabular}

C: cannot be computed.

Results of the descriptive for the factors contained in Table 1 shows that adoption of social entrepreneurial practices was positively and significantly correlated to the type of management (whether direct or contract). It was also highly though negatively correlated to business locality. As was expected, outcome was highly correlated to adoption of social enterprise strategy and length of operation. Further exploratory Chi - square analysis showed that at .05 level of significance, type of management and the location of the enterprise had a significant influence on their having documented social enterprise strategy, $\mathrm{X}^{2}=6.857 ; \mathrm{df}=1 ; \mathrm{P}=.009 ;$ and $\mathrm{X}^{2}=11.598 ; \mathrm{df}=3 ; \mathrm{P}=.009$ respectively. Specifically, Contingency coefficient measure of association indicated that $28.1 \%$ of the variation in having a documented social enterprise strategy could be attributed to type of management, cross tabulation showing that direct management registered highest tendency of adoption of social enterprise strategy. Similarly, contingency coefficient measure of association showed that $35.6 \%$ of the tendency could be attributed to the location of hospitality investments, those investments in Taita Taveta and Kwale having highest level of adoption of the strategy while those in Mombasa County had the least. The implication is that making a deliberate attempt to adopt social enterprise strategy by hoteliers is mutually exclusive to the type of management and business location. Additionally, 
investments existing within more rural counties such as Taita Taveta and Kwalewere shown to be highly motivated to adopt social enterprise strategy than urban counties such as Mombasa.

\subsection{Social Enterprise Strategy}

The study to begin with, attempted to determine the extent to which operators in the hospitality industry had adopted social enterprise strategy. Data obtained relative to this objective were as presented in Table 2.

Table2. Social Enterprise Strategy

\begin{tabular}{|lll|}
\hline Component & Mean & SD \\
\hline Social mission & 3.50 & 1.40 \\
Positive externalities (spill overs ) for society & 4.25 & 1.02 \\
Entrepreneurial function & 3.67 & 1.19 \\
Market competitiveness & 3.83 & 1.22 \\
\hline
\end{tabular}

The findings show that a majority of respondents, 45 (56.3\%)had a documented social enterprise strategy. In particular, a majority indicated that the document addressed itself to positive externalities (spill overs) for the society $(\mathrm{M}=4.25, \mathrm{SD}=1.02)$, market competitiveness $(\mathrm{M}=3,83, \mathrm{SD}=1.22)$, entrepreneurial function $(\mathrm{M}=3.67, \mathrm{SD}=1.19)$ and social mission $(\mathrm{M}=3.50, \mathrm{SD}=1.40)$ in decreasing order of extent of effect according to the respondents.For them, the document was meant to achieve mainly two goals; the first goal entailing social, cultural, community, economic and or environmental outcomes according to $65(86.7 \%)$ and the second being to earn revenue according to $60(80.1 \%)$ of the respondents. A majority of those who did not have a documented social enterprise strategy indicated either not having thought about having it or were in the process of developing one. The results imply that a significant proportion of hospitality industry entrepreneurs within the coastal tourism circuit in Kenya have made a conscious effort to integrate their operations into the social fabric of the communities around them.

\subsection{Demographics and Social Entrepreneurship}

Secondly, the study attempted to determine the link between hospitality industry entrepreneurs' background characteristics and their adoption of social entrepreneurship. Background factors considered for review type of establishment, type of management, length of operation and location of the enterprise. Frequency and percentage were used to illustrate operators' descriptive while regression analysis was used to infer on the existing relationship. Data obtained illustrated that the respondents included $5(6.3 \%)$ directors, $5(6.3 \%)$ CEOs and $70(87.5 \%)$ general managers. They were drawn from30 (37.5\%) establishment in Mombasa county, 15 (18.7\%) were from Kilifi county, $25(31.3 \%)$ were from Kwale while the remaining 10 (12.5\%) were from Taita Taveta county. A majority of the establishment, $76(95 \%)$ were vocational hotels while $4(5 \%)$ were lodges. Further, it was established that $75(93.8 \%)$ were under direct management while a paltry $5(6.3 \%)$ were under contract management. Lastly, it was established that $35(43.8 \%)$ of the established had been in operation for a period less than ten years, 15 (18.7\%) for between ten and twenty years and the remaining 30 (37.5\%) for more than twenty years. Results from the regression analysis used to infer on the existing relationship were as summarised in Table 3.

Table3. Regression Analysis of Adoption of Social Enterprise Strategy

\begin{tabular}{|llccc|}
\hline Variables & $\mathrm{B}$ & $\beta$ & $\mathrm{t}$ & $\mathrm{p}$ \\
\hline Establishment type & -.160 & -.141 & -1.278 & .205 \\
Management type & .754 & .368 & 3.481 & .001 \\
Operation length & -.175 & -.318 & -2.839 & .006 \\
Business location & -.138 & -.299 & -2.660 & .010 \\
\hline
\end{tabular}

Table 3 contains data obtained from a linear regression analysis of the existing relationship between operators' background factors and adoption of social enterprise strategy. The regression model used showed that the background factors accounted for $24.3 \%$ of the total variance in adoption of social enterprise strategy $F(4,80)=6.00, \mathrm{p}<.001$. The model which was found to be significant showed that type of establishment has an insignificant negative influence $(\beta=-0.160, p=.205)$ on adoption of social enterprise strategy, type of management was found to have a positive significant influence ( $\beta=$ 0.754, $\mathrm{p}=.001$ ) confirming the observations from descriptive statistics. Additionally, length of operation and location of the enterprise were each found to have a significant negative influence, $(\beta=-0.175, p=.006)$ and $(\beta=-0.138, p<.010)$ respectively. It could therefore be concluded that among 
the background factors, type of management, business location and length of operation are significant determinant of their adoption of social entrepreneurial practices with that of type of management being positive.

\subsection{Outcomes of Social Entrepreneurship}

The study also aimed at determining the outcome of adoption of social entrepreneurial practices. This was gauged based on two factors; social, cultural, community and or environmental factors and social economic factors. Results drawn from social, cultural, community and or environmental factors were as summarized in Table 4.

Table4. Outcome of Social, Cultural, Community and or Environmental Factors

\begin{tabular}{|lcccc|}
\hline Component & Response GE \& VGE & Mean & SD \\
& $\mathrm{f}$ & $\%$ & & \\
\hline Eradication of child labour & 65 & 81.3 & 4.31 & 1.45 \\
Youth empowerment & 65 & 81.3 & 4.00 & 1.23 \\
Women employment & 55 & 68.8 & 3.81 & 1.24 \\
Eradication of child sex tourism & 70 & 87.5 & 4.56 & 1.18 \\
Equal opportunity & 60 & 75.0 & 4.19 & 1.14 \\
Initiatives for green economy & 65 & 81.3 & 4.06 & 1.31 \\
Involvement of the local community in supplies & 75 & 93.8 & 4.56 & 1.00 \\
Employment of local community residents & 70 & 87.5 & 4.38 & 1.06 \\
Ownership & 35 & 43.8 & 3.25 & 1.49 \\
Preservation of local culture & 60 & 75.0 & 4.06 & 1.44 \\
\hline
\end{tabular}

Results of the outcome of operators' adoption of social enterprise strategy according to a majority of the respondents was found to be greatest for involvement of the local community in supplies to the facilities (93.8\%) followed by employment of local community residents and eradication of child sex tourism (87.5\%) then eradication of child labour, youth empowerment and initiatives for green economy $(81.3 \%)$. Preservation of local culture and provision of equal opportunity also received relatively high rating as outcome of adoption (75.0\%). Similarly women employment received slightly more than average rating (68.8\%) though involvement of the locals in ownership of the enterprises received the least rating $(43.8 \%)$. On further probing with regard to eradication of commercial exploitation of children and child sex tourism, $60(75 \%)$ of the entrepreneurs acknowledged having signed the code which according to a majority of them were strictly being enforced within their premises. Table 5 presents additional findings on outcomes of socioeconomic factors.

Table5. Outcome of Socioeconomic Factors

\begin{tabular}{|lcccc|}
\hline Component & \multicolumn{2}{c}{ Response GE \& VGE } & Mean & SD \\
& $\mathrm{f}$ & $\%$ & & \\
\hline Shareholding & 25 & 31.3 & 2.73 & 1.35 \\
Distribution of profit revenue & 25 & 31.3 & 2.93 & 1.30 \\
Competition within the market & 45 & 56.3 & 3.67 & 1.26 \\
Observation of statutory requirements as & 65 & 81.3 & 4.53 & 1.09 \\
regards payments and compensations for & & & & \\
labour, supplies and other services. & & & & \\
Manpower development & 65 & 81.3 & 4.20 & 1.05 \\
\hline
\end{tabular}

Table 5 contains data on the socioeconomic outcomes. The findings show that according to the respondents, manpower development and observation of statutory requirements as regards payments and compensations for labour, supplies and other services were the most prominent socioeconomic outcome as enumerated by $65(81.3 \%)$ followed by competition within the market $(56.3 \%)$ and lastly embracing shareholding as well as distribution of profit revenue $(31.3 \%)$ in decreasing order of effect. In general, it was observed that a majority of the respondents acknowledged that their adoption of social entrepreneurial practices had positively impacted operations particularly in light of their day to day interactions with the local communities. Patel (2014) posits that social entrepreneurs may see an increase in profit as stakeholders attempt to implement social enterprise strategy. Quoting a 2013 study by Cone Communications/ Echo Global CSR as cited in the Cause Marketing Forum, the researcher notes that "91 percent of global consumers are likely to switch brands to one associated with a good cause, given comparable price and quality."In addition, customers are also more willing 
to actually spend more for products when they know the company is giving back: "50 percent of global consumers said they would be willing to reward companies that give back to society by paying more for their goods and services", cites a Nielsen 2013 Consumers Who Care Study.

\subsection{Challenges}

Lastly the study set out to establish the challenges that hospitality industry operator's encounter in the course of their operations that could either limit or inhibit achieving goals of adoption of social entrepreneurial practices. Results indicate that according to a majority of the respondents, factors considered to pose challenges include market volatility of the sector which most often depressed accruing revenue thus leading to financial constraints, restraints due to legal and logistical issues and limited capacity of the local communities to cooperate in provision of some required essential supplies and services. Others include negative perception of some stakeholders about the concept and its practice which most often culminated into minimal cooperation. This finding corroborates that of Munoz (2009) who observed that social entrepreneurs encounter implementation difficulties, the challenges being more compounded in foreign locations. Similarly, Ahlstrom et al (2000) laments on the existence of numerous challenges for growing small businesses in China. In particular, Munoz (2009) intimated that inadequacy of support is of primary concern an aspect also supported by Theobald (1987) who observed lack of societal support for the efforts of social entrepreneurs.

\section{IMPLiCATIONS, LiMitATIONS AND CONCLUSIONS}

\subsection{Implications}

The findings show that a considerable proportion of hospitality industry players within the coastal tourist circuit in Kenya have to some degree embraced social entrepreneurial practices. This according to some of them has not only improved their level of interaction with local communities but also generally impacted the way they do business which is a move in the right direction particularly in fostering the relationship between the investors and the community around them.

\subsection{Limitations and Directions for Further Research}

This study though significant has a number of limitations. The quantitative research methodology adopted was mainly based on self-report measures which future studies could build on. Probably, longitudinal studies could particularly be more appropriate since they may be helpful in tracking changes in thinking processes and related socioeconomic issues. Additionally, the findings of the present study should be interpreted in a careful way since a convenience sampling procedure was applied. Respondents were drawn exclusively from among membership of KAHC that the researchers could readily access which could have caused uncontrolled bias. Lastly, lack of empirically tested instrument for testing extent of adoption of social entrepreneurial practices may have limited the quality of data obtained to some extent.

\subsection{Conclusion}

Our study has provided an insight on adoption of social entrepreneurship, a Kenyan context. The findings show that a number of investors in the hospitality industry have embraced social entrepreneurial practices in their operations with positive impact on their operations. A number of investments indicated being involved in programs that were not only useful in raising revenue for their businesses but also improving the livelihood of the local communities which underpins the basic tenets of social entrepreneurship. The results provide a foundation on which current and future players in the industry as well as researchers in social entrepreneurship could improve on.

\section{REFERENCES}

Ahlstrom, D., Bruton, G., Lui, S., (2000). Navigating China's changing economy: Strategies for private firms. Business Horizons, 43(1), 5-15, 2000.

Austin, J Stevenson, H and Wei-Skillern, J (2006). 'Social and Commercial Entrepreneurship: Same, Different, or Both?' Entrepreneurship Theory \&Practice, Vol.30, No. 1, pp.1-22.

Black, L and O'Brien, D 2004. From Community Project to Commercial Venture: The Case of REAP Kenya. A presentation on Agribusiness Models and Innovation of Private Sector Linkages, tober, 2004, viewed 18 March 2012, http://www.authorstream.com

Bohdanowicz, P., \&Zientara. P. (2008).Hotel companies contribution to improving the quality of life of local communities and the wellbeing of their employees. Tourism and Hospitality Research, 9 (2), 147-158 
Davis, S. (2002). Social entrepreneurship: towards an entrepreneurial culture for social and economic development. (Accessed January 2016), [available at: http://www.ashoka.org/global/ yespaper.pdf],.

Desa, G. (2007). Social entrepreneurship: snapshots of a research field in emergence. Paper presented at the 3rd International Social Entrepreneurship Research Conference, Copenhagen.

Dzisi, S. \& Otsyina, F. A. (2014).Exploring Social Entrepreneurship in the Hospitality Industry. International Journal of Innovative Research \& Development, Vol 3 Issue 6 pp 233-241

Ergul, M., \& Johnson, C. (2011). Social entrepreneurship in the hospitality and tourism industry: an exploratory approach. The Consortium Journal of Hospitality and Tourism, 16(2), 40 - 46.

Ewart, T.(2005), CARE Kenya: Making Social Enterprise Sustainable. Case Study Ref no. B05M056. Richard Ivey School of Business.

Irandu, E. M. (2004). The role of tourism in the conservation of cultural heritage in Kenya. Asia Pacific Journal of Tourism Research, Vol. 9, No. 2, pp 133-150.

Mort, G.S., Weerawardena, J., Carnegie, K., (2003). Social entrepreneurship: Towards conceptualization. International Journal of Nonprofit and Vountary Sector Marketing 8 (1) (Feb 2003), p. 76-88.

Moufakkir, O and PM. Burns (2012) Introduction. In Mouffakir, Omar and Peter. M.Burns (eds) Controversies in Tourism. Oxford CABI Publishing.

Munoz, M. J. (2009). Social Entrepreneurship in China: Trends and Strategic Implications. Buletinul. Vol. 61(2) pg $1-12$.

Omondi, R. K. (2003). Gender and the political economy of sextourism in kenya's coastal resorts. A paper first presented at the International Symposium/Doctorial Course on Feminist Perspective on Global Economic and Political Systems and Women's struggle for Global Justice at Sommoroya Hotel, Tromso, Norway, September 24 -26, 2003

Overholt, A., Dahle, C., Canabou, C., (2004). Social capitalists. Fast Company (78), (January 2004), p. $45-57$.

Paquet, G., (1997). "States, Communities and Markets: The Distributed Governance Scenario" in Courchene, T. J. ed., The Nation-State in a Global Information Era: Policy Challenges The Bell Canada Papersin Economics and Public Policy, 5, (Kingston: John Deutsch Institute for the Study of Economic Policy) pp.25-46, 1997.

Rametse, N.,\& Shah, H. (2013).Investigating Social Entrepreneurship in Developing Countries. World Review of Business Research Vol. 3.No. 2.March 2013 Issue. Pp. 95 - 112

Thompson, J., Alvy, G., Lees, A., (2000) Social entrepreneurship - a new look at the people and thepotential. Management Decision (38) 5, p. 328, 2000.

World Bank (2010). Kenya's Tourism: Polishing the Gem. Finance and Private Sector Development Africa Region.

\section{AuthORS' BIOGRAPHY}
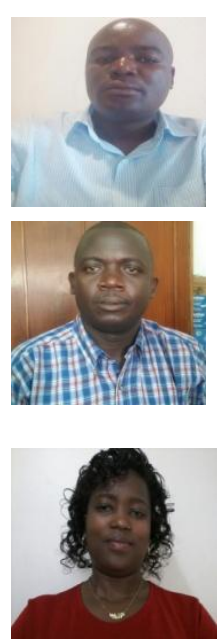

Mr Sam Ikwaye, is the Executive Officer of the Kenya Association of Hotel Keepers and Caterers Coast branch. Currently a $\mathrm{PhD}$ in Business Administration student at the Kenya Methodist University, Ikwaye also holds an MBA (Entrepreneurship) from the Kenya Methodist University.

Mr. John Ogembo, is an experienced educationist withover 15 years teaching experience both at secondary and tertiary levels. An author on a wide range of themes ranging from educational to socioeconomic related topics, Mr. Ogembo is currently a lecturer at the South Eastern Kenya University (SEKU) and a $\mathrm{PhD}$ candidate at Kenyatta University.

Mrs Bernadett Kiarie, is an educationist with 17 years teaching experience. Currently a teacher at Kianda school in Nairobi, she is also a $\mathrm{PhD}$ student at the Kenyatta University in the Department of Educational Communication and Technology. 